\title{
Achieving Sustainable Development Goals 2016-2030 in Nigeria through Female Enrolment into Electrical/Electronics Engineering Trade in Technical Colleges of Adamawa State
}

\author{
Dauda Moses ${ }^{1}$, Aniekan Elijah Asukwo², Muhammed Adamu Yusuf ${ }^{3}$, Isaac John Ibanga ${ }^{4}$ \\ ${ }^{1,2,3}$ Department of Electrical Technology Education, Modibbo Adama University of Technology, Yola, \\ Adamawa State, Nigeria. \\ ${ }^{4}$ Akwa Ibom State Ministry of Education, Uyo, Akwalbom State, Nigeria.
}

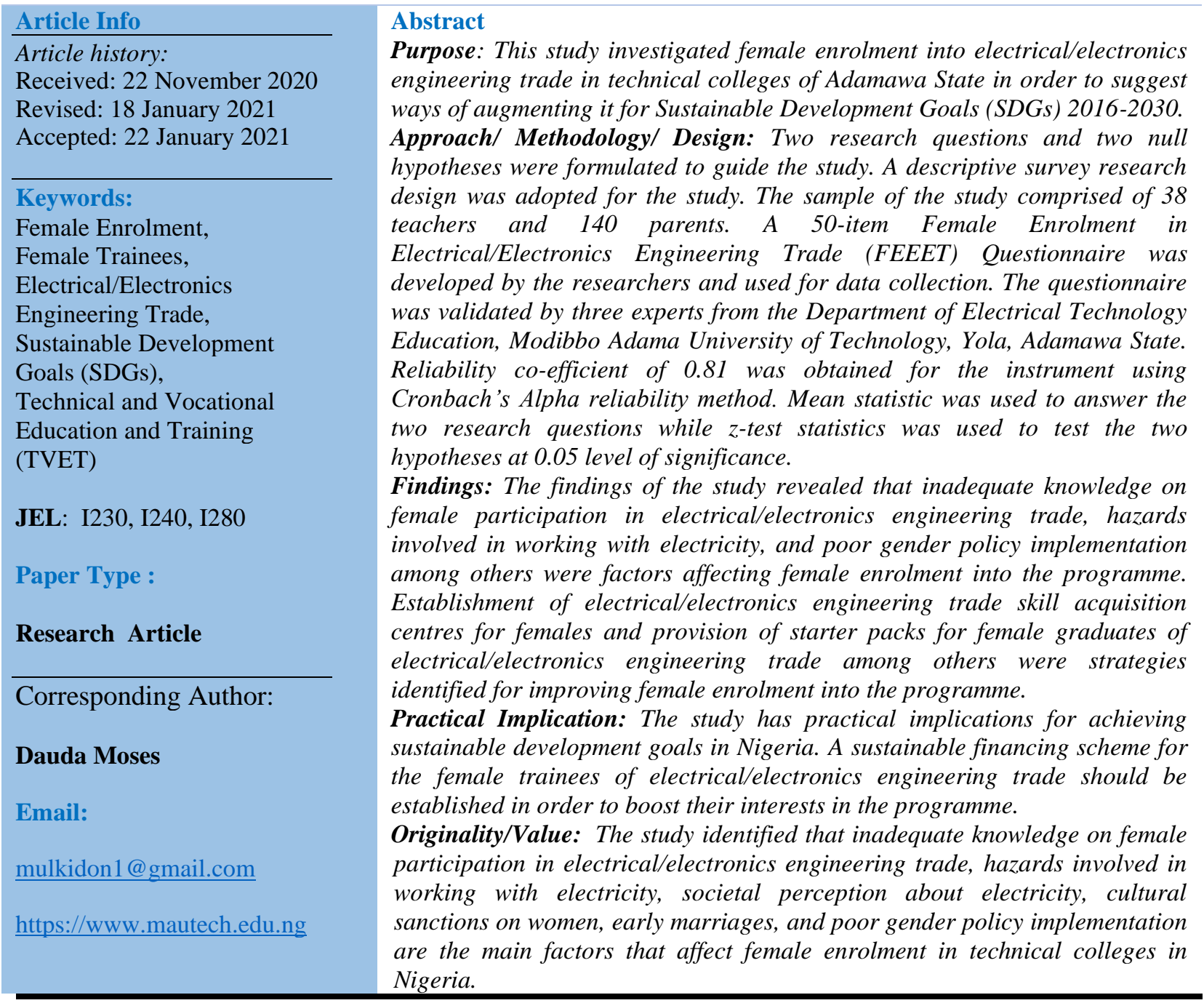

\section{Introduction}

The statistical records of students' enrolment for the three Government Science and Technical Colleges (GSTC) of Adamawa State disclosed a decline in the enrolment of female students into electrical/electronics engineering trade. For instance, in 2016/2017 session, out of 365 students that were enrolled, $90.68 \%$ (331 students) were males and 9.32\% (34 students) were females. 
There was a further decline in 2017/2018 session as 392 students were enrolled, of which 92.88\% (364 students) were males and 7.12\% (28 students) were females. A more decline in the enrolment of female students was experienced in the 2018/2019 session as out of 362 students that enrolled, only $4.70 \%$ (17 students) were females and $95.30 \%$ (345 students) were males (Apagu, et al., 2003).

The above report points to a quick decline in female students' enrolment into electrical/electronics engineering trades in the technical colleges of Adamawa State. If this decline in female students' enrolment is not addressed urgently, the electrical/electronics engineering trades of the technical colleges in Adamawa state might end up having no female students' enrolment in the program in the near future. It is against this background that this study sought to ascertain the factors affecting female enrolment in electrical/electronics engineering trade in the technical colleges of Adamawa State while also ascertaining strategies to augment their enrolment as a means of achieving sustainable development goals.

The Sustainable Development Goals (SDGs) define the world we want. They apply to all nations and mean, quite simply, to ensure that no one is left behind and realizing such dreams was almost always up to national Governments. And, in the spirit of leaving no one behind, it is up to the United Nations and all its partners and supporters to ensure that everyone has access to the SDGs and their inclusive message (Allen, 2016). That means that the UN, unlike purely commercial ventures, must preserve, as long as they are relevant, the 'old' means of communication. Radio, for instance, is still the only way to reach a higher percentage of population, living mostly in rural areas where the Internet has not yet penetrated.

According to Abel (2016), in virtual reality, digitally connected, experimenting every few seconds with images and accustomed to change at the press of a button. Their universe is visual. The 21st century is an era of exponential technological advancement. Current society has become more dependent on technology in contrast to any other epoch in history. Regardless of occupation or geographic location, technology continually impacts and regulates our lives. Individuals who are technological literate are able to use, manage, assess, and understand technology. Unfortunately, a large percentage of female Nigerian citizens have entered the 21 st century technologically illiterate due to lack of poor enrolment in technologically inclined courses. Many middle aged or older citizens claim that they are deficient in technological knowhow due to the lack of technically exposure as a child, it is essential that young people are introduced and immersed in technology to facilitate their preparation for the future that will enhanced and sustained development (Buse, 2015).

It is hoped that the findings of this study will help encourage the participation of female students in acquiring skills in electrical/electronics engineering trade in technical colleges of Adamawa State while also providing the policy makers and educational planners with necessary information for more effective educational planning and better policy formulation to improve female participation in electrical/electronics engineering trade. It is expected that the Adamawa communities will also benefit from the findings of the study, as it will encourage the female aspirants to pursue careers in electrical/electronics engineering trade which will in turn equip 
them for self-reliance, thereby reducing crimes, prostitution and other social vices among females and also changing the general perception of the society towards female participation in TVET in general.

\section{Literature Review}

The Sustainable Development Goals (SDGs) are a collection of 17 global goals set by the United Nations General Assembly in 2015 for the year 2030. The goals which include Quality Education and Gender Equality bolsters the United Nations' commitment to end poverty, and are unique in that they cover issues that affect various nations. The 17 SDGs interconnect, therefore inferring that a success in one brings about a success for others e.g. achieving gender equality or inclusiveness will help alleviate poverty. According to the United Nations Development Programme (2019), the belief that education is one of the most powerful and proven vehicles for sustainable development is reaffirmed by achieving inclusive and quality education for all. Unfortunately, the Nigerian society has stereotyped some occupation and education to certain gender thereby discouraging the other from either benefiting from the programme or playing active role in its survival and effectiveness to help sustain development in the society (Ibanga, et al., 2019).

Electrical/electronics engineering trade is one of the Technical and Vocational Education and Training (TVET) programs with the objective to produce craftsmen and women that will maintain, service and repair electrical equipment/gadgets and electronics appliances such as cassette players, radio, television among others and to wind electrical machines, wiring and installation of both domestic \& industrial installations, etc. (Akinduro, 2006). However, employers of labour feel reluctant to employ the few available female graduates of electrical/electronics engineering trade probably because of their perceptions toward female occupational choice and consequently, the female craftsmen have low patronage from the society when they try to be self-reliant (West, 2007). This unwillingness to employ craftswomen contradicts World Health Organization (2009) which described gender equity as fairness and justice in the distribution of benefit and responsibilities between women and men. Robert (2005) maintained that females have less access (opportunities) to education in Nigeria as compared to males. This poor enrolment is further accentuated in female enrolment in Technical, Vocational Education and Training (Ezeliora \& Ezeokana, 2010). Gender differences in various fields of education have been reported and this gender imbalance also affects the mode of enrolment in electrical/electronics engineering trade as observed by Josiah and Etuk (2014).

Okwelle and Agwi-Vincent (2018) determine the strategies for improving female students' enrolment in technical and vocational education and training programmes in Nigeria through students' involvement in public relations activities. The study adopted descriptive survey design approach. The population includes 365 final year technical education students and 68 technology education lecturers in the three tertiary institutions in Rivers State that offer programmes in technical education. The sample was drawn from this population, and it comprised 120 technical education final year students and 68 technology education lecturers The simple random sampling technique was used in selecting the respondents. Data were analyzed 
using mean, standard deviation and t-test statistics. The findings of this study revealed among other things, that the following strategies among others were identified for improving female students enrolment in TVET programmes through female students involvement in public relations; effective supervision of students on industrial training and teaching practice, introducing public relations activities into the school curriculum and sponsoring and participating in students organizations and programmes. It was recommended among others that institutions should establish and fund public relation unit without wasting time, school public relation officers should ensure that they carry their TVE students along during public relation activities.

In another related study, Khaguya (2014) examined the factors influencing female students' enrolment in technical courses. The study adopted case study research design. The study employed the Krejcie and Morganformulaeandasamplesizeof219wasused. In this study multiple regressions were used to analyze data. The findings revealed that cultural factors such early marriages, female genital mutilation, cultural beliefs and time spent on doing household chores make girl to have little time to devote to their academic work. It was also revealed that financial factors such the fees paid for the technical courses, expensive learning materials and books made parents to discourage their daughters on choosing the technical courses. The girls are also not informed about possible future salaries and their abilities and are therefore not motivated to choose technical courses. Psychological factors also influenced the enrolment. The findings show that majority of the respondents indicated that technical courses are masculine and are meant to be pursued by boys. The study also revealed that girls perform equally well on many technical skills and attitudes assessment in the elementary school years and what they need is role models to encourage them to pursue the technical courses in their tertiary education programmes.

In a study conducted by Angelopulo (2013) identified the drivers of students' student enrolment and retention in the academic programmes of a South African. The research was undertaken amongst a diverse group of students, faculty, support and oversight staff, chosen to represent as wide a range of opinions on the topic as possible. Q methodology was used to categorize the variety and span of subjective opinion on the market-related, service quality and cultural variables that support or undermine student participation in the department's academic programmes. Eight richly diverse accounts were derived, reflecting the most salient perceptions on the topic. Underlying factors that supported student enrolment and retention were the reputation, credibility and image of university and department, and specific academic, disciplinary, technical and administrative competencies. The study revealed that the main factors that undermined enrolment and retention were the scope of research and tuition, institutional performance, inconsistency in teaching quality and the relative inaccessibility of tuition material.

\section{Methodology and Procedures}

The study adopted a descriptive survey research design. The study involved the use of a structured questionnaire to elicit information from the parents and teachers of electrical/electronics engineering trade in the government technical colleges of Adamawa state. 
Two research questions and two null hypotheses were developed and formulated respectively to guide the study. The study had a total population of 258 respondents comprising 38 teachers and 220 parents of students enrolled into electrical/electronics engineering trade in the three technical colleges of Adamawa state. The sample was 178 respondents comprising 38 teachers and 140 parents. The entire population of teachers was used, while Krejcie and Morgan (1970) table was used to determine the sample size of parents that were used for the study. Proportionate random sampling was then used to select the 140 parents. A structured Female Enrolment in Electrical/Electronics Engineering Trade (FEEET) Questionnaire developed by the researchers was used for data collection. The responses to the questionnaire were structured on 5-point Likert scale of Strongly Agreed $(\mathrm{SA})=5$, Agreed $(\mathrm{A})=4$, Undecided $(\mathrm{U})=3$, Disagreed $(\mathrm{D})=2$ and Strongly Disagreed $(\mathrm{SD})=1$. The questionnaire was validated by three experts from Department of Electrical Technology Education, Modibbo Adama University of Technology, Yola, Adamawa State. The reliability co-efficient of 0.81 was obtained for the instrument using Cronbach's alpha reliability method. Mean statistic was used to answer the two research questions and z-test was used to answer the null hypotheses at 0.05 level of significance. All items with a mean score of 3.50 and above were considered agreed, while items with mean score less than 3.50 were considered disagreed. Any hypothesis with $p$ value less than or equal to 0.05 was regarded as significant; otherwise, it was not significant.

\section{Results and Discussion}

\section{Research Question 1}

What are the factors affecting female enrolment into electrical/electronics engineering trade in technical colleges of Adamawa state?

Table 1: Mean responses of teachers and parents on the factors affecting female enrolment into electrical/electronics engineering trade in technical colleges of Adamawa State

\begin{tabular}{|c|c|c|c|c|c|c|c|c|}
\hline \multirow[t]{2}{*}{$\mathbf{S} / \mathbf{N}$} & \multirow[t]{2}{*}{ Items } & \multicolumn{7}{|c|}{ Respondents } \\
\hline & & $\bar{x}_{T}$ & $\sigma_{T}$ & $\bar{x}_{P}$ & $\sigma_{P}$ & $\bar{x}_{G}$ & $\sigma_{G}$ & Remarks \\
\hline 1 & $\begin{array}{l}\text { Inadequate knowledge of female participation in } \\
\text { electrical/electronics engineering trade }\end{array}$ & 4.68 & 0.64 & 4.59 & 0.22 & 4.61 & 0.64 & Agreed \\
\hline 2 & Hazards involved in working with electricity & 4.26 & 0.47 & 4.37 & 0.19 & 4.34 & 0.89 & Agreed \\
\hline 3 & Societal perception about working with electricity & 4.50 & 0.56 & 4.44 & 0.20 & 4.46 & 0.94 & Agreed \\
\hline 4 & Rigid enrolment criteria & 3.92 & 0.37 & 3.89 & 0.14 & 3.90 & 0.77 & Agreed \\
\hline 5 & High cost of fees charged & 4.13 & 0.43 & 3.02 & 0.10 & 3.32 & 0.74 & Agreed \\
\hline 6 & High cost of raw materials for practical project & 4.05 & 0.41 & 3.17 & 0.10 & 3.41 & 0.73 & Agreed \\
\hline 7 & Poor gender policy implementation & 4.21 & 0.46 & 4.20 & 0.17 & 4.20 & 0.86 & Agreed \\
\hline 8 & Incessant bullying of females by male folks & 3.95 & 0.38 & 3.23 & 0.07 & 3.38 & 0.72 & Agreed \\
\hline 9 & Inadequate security for female & 4.18 & 0.45 & 3.71 & 0.12 & 3.84 & 0.79 & Agreed \\
\hline 10 & Gender biased NBTE curriculum materials & 3.40 & 0.39 & 2.95 & 0.10 & 3.09 & 0.73 & Disagreed \\
\hline 11 & Poor provision of qualified technical teachers & 3.32 & 0.28 & 3.59 & 0.13 & 3.51 & 0.69 & Agreed \\
\hline 12 & Poor scholarship scheme for female students & 3.97 & 0.39 & 3.40 & 0.11 & 3.56 & 0.73 & Agreed \\
\hline 13 & Poor parental perceptions towards female education & 4.55 & 0.58 & 4.10 & 0.16 & 4.22 & 0.90 & Agreed \\
\hline 14 & Cultural sanctions on women & 4.32 & 0.49 & 4.08 & 0.16 & 4.14 & 0.86 & Agreed \\
\hline 15 & Lack of family and peers support & 3.76 & 0.34 & 3.75 & 0.13 & 3.75 & 0.74 & Agreed \\
\hline 16 & Early marriages & 4.21 & 0.46 & 4.10 & 0.16 & 4.13 & 0.84 & Agreed \\
\hline 17 & $\begin{array}{l}\text { Lack of female technical teachers to serve as role } \\
\text { models }\end{array}$ & 4.16 & 0.44 & 3.58 & 0.11 & 3.74 & 0.77 & Agreed \\
\hline
\end{tabular}




\begin{tabular}{|c|c|c|c|c|c|c|c|c|}
\hline 18 & Poor primary education at entry level & 3.87 & 0.36 & 4.19 & 0.17 & 4.10 & 0.81 & Agreed \\
\hline 19 & Students poor exposure to the world of work & 4.18 & 0.45 & 3.65 & 0.12 & 3.79 & 0.78 & Agreed \\
\hline 20 & Perceived ideal roles of female at home & 3.37 & 0.28 & 4.23 & 0.17 & 3.99 & 0.77 & Agreed \\
\hline 21 & $\begin{array}{l}\text { Female home chores are difficult to combine with } \\
\text { study }\end{array}$ & 3.47 & 0.29 & 2.92 & 0.10 & 3.07 & 0.67 & Disagreed \\
\hline 22 & $\begin{array}{l}\text { Lack of awareness on the objective and prospects } \\
\text { of electrical/electronics engineering trade }\end{array}$ & 3.82 & 0.35 & 3.83 & 0.13 & 3.83 & 0.76 & Agreed \\
\hline 23 & $\begin{array}{l}\text { Poor societal attitude towards technical education } \\
\text { in general }\end{array}$ & 3.58 & 0.31 & 4.06 & 0.15 & 3.93 & 0.76 & Agreed \\
\hline 24 & $\begin{array}{l}\text { Societal perception that technical education is for } \\
\text { dull and unintelligent students }\end{array}$ & 3.87 & 0.36 & 3.84 & 0.13 & 3.85 & 0.76 & Agreed \\
\hline 25 & Poor societal recognition of technical education & 3.92 & 0.37 & 3.55 & 0.11 & 3.65 & 0.74 & Agreed \\
\hline 26 & $\begin{array}{l}\text { Societal perception that Technical Education is for } \\
\text { the less privileged }\end{array}$ & 3.89 & 0.37 & 4.23 & 0.17 & 4.14 & 0.82 & Agreed \\
\hline 27 & Girls are considered as home makers & 4.29 & 0.54 & 3.82 & 0.13 & 3.94 & 0.82 & Agreed \\
\hline 28 & $\begin{array}{l}\text { Society perception of female students' abilities to } \\
\text { be less than that of their male counterparts }\end{array}$ & 4.13 & 0.27 & 3.87 & 0.10 & 4.00 & 0.66 & Agreed \\
\hline 29 & Child bearing & 4.00 & 0.39 & 3.94 & 0.14 & 3.96 & 0.79 & Agreed \\
\hline 30 & $\begin{array}{l}\text { Unwillingness of parents to allow girls to travel } \\
\text { long distances }\end{array}$ & 3.68 & 0.32 & 4.14 & 0.16 & 4.01 & 0.78 & Agreed \\
\hline & & 3.99 & 0.41 & 3.81 & 0.14 & 3.86 & 0.78 & \\
\hline
\end{tabular}

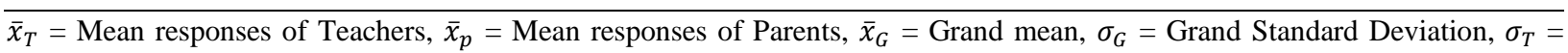
Standard Deviation of Teachers, $\sigma_{P}=$ Standard Deviation of Parents.

Source: Authors

Data presented in Table 1 above showed that the respondents (teachers and parents) agreed on almost all the factors affecting female enrolment in electrical/electronics engineering trade in technical colleges of Adamawa state base on the grand means which ranges from 3.07 to 4.61 except on two items. Specifically, the respondents did not consider a gender biased NBTE curriculum and difficulty of combining home chores with study as factors affecting female enrolments. Furthermore, with standard deviation ranging from 0.64 to 0.94 and a cluster deviation of 0.78 , the results also indicate that the opinions of the respondents are clustered around the mean response.

The respondents (teachers and parents) agreed on almost all the factors affecting female enrolment in electrical/electronics engineering trade in technical colleges of Adamawa state which include inadequate knowledge on female participation in electrical/electronics engineering trade, hazards involved in working with electricity, societal perception about electricity, cultural sanctions on women, early marriages, and poor gender policy implementation among others. However, the respondents did not consider a gender biased NBTE curriculum and difficulty of combining home chores with study as factors affecting female enrolments.

The findings of the study revealed that inadequate knowledge on female participation in electrical/electronics engineering trade, hazards involved in working with electricity, societal perception about electricity, poor gender policy implementation, poor parental perceptions towards female education, cultural sanctions on women, early marriages, poor primary education background at entry level, and unwillingness of parents to allow girls to travel long distances are major factors affecting female enrolment into electrical/electronics engineering trade in technical 
colleges of Adamawa state. The findings above are in line with Gimba (2008) who maintained that poverty and lack of awareness affects female enrolment into formal school in northern Nigeria. In support of this view, Amoo (2011) maintained that enrolment of female or girl-child is even worse in the northern Nigeria due to parents' attitude toward western education. Ayomike (2014) opined poor societal perception, poor entry level, lack of recognition and discrimination against graduates of technical vocational education (TVE) are some of the factor affecting female enrolment in TVET. The results of this study are in line with the previous studies indicating that the absence of policy implementation majorly affects female enrolment into technical/engineering colleges in Nigeria. More importantly, it is recognized that the media and society have not played an active role in dismantling the stereotypes associated with this type of education.

\section{Research Question 2}

What are the strategies for improving female enrolment into electrical/electronics engineering trade in technical colleges of Adamawa state?

Table 2: $\quad$ Mean responses of teachers and parents on the strategies for improving female enrolment into electrical/electronics engineering trade in technical colleges of Adamawa state

\begin{tabular}{|c|c|c|c|c|c|c|c|c|}
\hline \multirow{3}{*}{$\mathbf{S} / \mathbf{N}$} & \multirow{3}{*}{ Items } & \multicolumn{7}{|c|}{ Respondents } \\
\hline & & \multicolumn{2}{|c|}{$\mathrm{N}_{\mathrm{T}}=38$} & \multicolumn{2}{|c|}{$N_{P}=140$} & \multirow[b]{2}{*}{$\bar{x}_{G}$} & \multirow[b]{2}{*}{$\sigma_{G}$} & \multirow[b]{2}{*}{ Remarks } \\
\hline & & $\bar{x}_{T}$ & $\sigma_{T}$ & $\bar{x}_{P}$ & $\sigma_{P}$ & & & \\
\hline 1 & $\begin{array}{l}\text { Establishment of electrical/electronics engineering } \\
\text { trade skill acquisition centres for females }\end{array}$ & 3.66 & 0.32 & 4.41 & 0.20 & 4.21 & 0.51 & Agreed \\
\hline 2 & $\begin{array}{l}\text { Employment of female technical trainers to serve as } \\
\text { role models }\end{array}$ & 3.95 & 0.38 & 3.58 & 0.11 & 3.68 & 0.74 & Agreed \\
\hline 3 & $\begin{array}{l}\text { Creating conducive environment for would-be } \\
\text { practicing female technicians }\end{array}$ & 4.05 & 0.40 & 4.09 & 0.16 & 4.08 & 0.82 & Agreed \\
\hline 4 & $\begin{array}{l}\text { Sensitization of all by government and policy } \\
\text { makers on the benefits of electrical/electronics } \\
\text { engineering trade }\end{array}$ & 3.84 & 0.36 & 4.36 & 0.19 & 4.22 & 0.83 & Agreed \\
\hline 5 & $\begin{array}{l}\text { Provision of starter packs for female graduates of } \\
\text { electrical/electronics engineering trade }\end{array}$ & 4.24 & 0.46 & 4.10 & 0.16 & 4.14 & 0.85 & Agreed \\
\hline 6 & Enforcement of law that bans female child labour & 4.53 & 0.57 & 3.91 & 0.15 & 4.09 & 0.87 & Agreed \\
\hline 0 & $\begin{array}{l}\text { poverty alleviation program } \\
\text { poven girls eaucation and }\end{array}$ & 3.66 & 0.32 & 4.22 & 0.10 & 3.84 & 0.69 & Agreed \\
\hline 7 & Use of media to change stereotyped expectations & 4.16 & 0.44 & 4.33 & 0.19 & 4.29 & 0.87 & Agreed \\
\hline 8 & $\begin{array}{l}\text { Provision of sponsorship to outstanding female } \\
\text { trainees upon graduation to higher institutions }\end{array}$ & 4.34 & 0.28 & 4.18 & 0.10 & 4.22 & 0.66 & Agreed \\
\hline 9 & $\begin{array}{l}\text { Career guidance and counselling on } \\
\text { electrical/electronics engineering trade be provided } \\
\text { to all female students }\end{array}$ & 4.05 & 0.41 & 3.57 & 0.11 & 3.70 & 0.76 & Agreed \\
\hline 10 & $\begin{array}{l}\text { Putting measures in place to safeguard against } \\
\text { gender bias in curricular presentation }\end{array}$ & 3.84 & 0.36 & 4.04 & 0.15 & 3.99 & 0.78 & Agreed \\
\hline 11 & $\begin{array}{l}\text { Legislating against offensive practices which are } \\
\text { detrimental to girl-child education }\end{array}$ & 3.84 & 0.36 & 4.41 & 0.20 & 4.26 & 0.84 & Agreed \\
\hline 12 & $\begin{array}{l}\text { Establishment of policies that will favour and } \\
\text { encourage women/girls education }\end{array}$ & 4.05 & 0.41 & 4.67 & 0.23 & 4.50 & 0.91 & Agreed \\
\hline 13 & $\begin{array}{l}\text { Follow-up evaluation of the implementation of the } \\
\text { law against discrimination of women in hiring and } \\
\text { promotion. }\end{array}$ & 4.05 & 0.41 & 4.25 & 0.18 & 4.20 & 0.84 & Agreed \\
\hline 14 & $\begin{array}{l}\text { Organization of awareness campaigns on prospects } \\
\text { of electrical/electronics engineering trade }\end{array}$ & 4.11 & 0.42 & 3.58 & 0.11 & 3.72 & 0.77 & Agreed \\
\hline 15 & $\begin{array}{l}\text { Provision of scholarship to female enrolees of } \\
\text { electrical/electronics engineering trade }\end{array}$ & 4.37 & 0.51 & 3.94 & 0.14 & 4.06 & 0.85 & Agreed \\
\hline
\end{tabular}


16 Show of commitment by government and stakeholders to a female-enhanced electrical/electronics engineering trade.

$\begin{array}{lllllll}3.97 & 0.39 & 3.45 & 0.11 & 3.59 & 0.74 & \text { Agreed } \\ 4.05 & 0.41 & 3.66 & 0.12 & 3.76 & 0.77 & \text { Agreed } \\ 4.42 & 0.53 & 3.76 & 0.13 & 3.94 & 0.83 & \text { Agreed } \\ & & & & & & \\ 3.37 & 0.51 & 3.92 & 0.10 & 3.31 & 0.78 & \text { Disagreed } \\ \mathbf{4 . 0 3} & \mathbf{0 . 4 1} & \mathbf{4 . 0 2} & \mathbf{0 . 1 5} & \mathbf{3 . 9 9} & \mathbf{0 . 7 9} & \end{array}$

$\overline{\bar{x}_{T}}=$ Mean responses of Teachers, $\bar{x}_{p}=$ Mean responses of Parents, $\bar{x}_{G}=$ Grand mean, $\sigma_{G}=$ Grand Standard Deviation, $\sigma_{T}=$ Standard Deviation of Teachers, $\sigma_{P}=$ Standard Deviation of Parents.

Data presented in Table 2 above showed that the respondents (teachers and parents) agreed on almost all the strategies for improving female enrolments into electrical/electronics engineering trade in technical colleges of Adamawa state base on the grand means which ranges from 3.21to 4.50 except on one item. Specifically, the respondents did not consider the downward review of admission requirements for females with interest in electrical/electronics engineering trade as a strategy for improving female enrolments. Furthermore, with standard deviation ranging from 0.51 to 0.91 and a cluster deviation of 0.79 , the results also indicate that the opinions of the respondents are clustered around the mean response.

The respondents (teachers and parents) agreed on almost all the strategies outlined for improving female enrolments into electrical/electronics engineering trade in technical colleges of Adamawa state which include establishment of electrical/electronics engineering trade skill acquisition centres for females, creating conducive environment for would-be practicing female technicians, and provision of starter packs for female graduates of electrical/electronics engineering trade among others. However, the respondents did not consider the downward review of admission requirements for females with interest in electrical/electronics engineering trade as a strategy for improving female enrolments.

The findings of the study also revealed that establishment of electrical/electronics skill acquisition centres for females, creating conducive environment for would-be practicing female technicians, provision of starter packs for female graduates of electrical/electronics engineering work trade, use of media to change stereotyped expectations, and establishment of policies that will favour and encourage women/girls education among others are strategies for improving female enrolment into electrical/electronics engineering trade in technical colleges of Adamawa state. Abdulahi (2016) suggested that greater public awareness and acceptance as well as in increased enrolments into TVET Programs will be achieved if the media is involved in the awareness campaign. Nawe (2002) suggested that improvement of school conditions, increasing schools facilities, teacher competence, systematic gender-sensitization programmes, introduction of quota system in enrolment; and gender-sensitive environment will enhance enrolment into TVET programs, electrical/electronics engineering trade inclusive. 


\section{Hypothesis 1}

There is no significant difference in the mean responses of parents and teachers on the factors affecting the enrolment of female students into electrical/electronics engineering trade in technical colleges of Adamawa State.

Table 3: $\quad$ z-test analysis of mean responses of teachers and parents on the factors affecting female enrolment into electrical/electronics engineering trade in technical colleges of Adamawa State

\begin{tabular}{lcccccccc}
\hline & $\bar{x}$ & $\sigma$ & $\mathrm{n}$ & $\mathrm{df}$ & $\alpha$ & $\mathrm{z}$ & $p$ & Remark \\
\hline Teachers & 3.99 & 0.41 & 38 & & & & & \\
& & & & 176 & 0.05 & 2.66 & 0.01 & Significant* \\
Parents & 3.81 & 0.14 & 140 & & & & & \\
\hline KEY: & $\bar{x}=$ Mean, $\sigma=$ Standard Deviation, $n=$ Number of Respondents, $d f=$ Degree of Freedom, $\alpha=$ level of \\
& $\begin{array}{l}\text { significance, } z=\text { Observed } z \text {-value, } p=\text { Significance (2-tailed }) \\
\text { Source: Authors }\end{array}$
\end{tabular}

The result on Table 3 reveals a z-value of 2.66 with a $p$-value of 0.01 . Since the $p$-value is less than the alpha level of the test $(p<.05)$, the null hypothesis tested is rejected. This means that there is a significant difference in the mean responses of parents and teachers on the factors affecting the enrolment of female students into electrical/electronics engineering trade in technical colleges of Adamawa State.

Findings from the study revealed that there was a significant difference in the mean responses of parents and teachers on the factors affecting the enrolment of female students in electrical/electronics engineering trade in technical colleges in Adamawa State. This is in nonconformity with Apagu, et al (2003) who revealed that even though there was disproportionate enrolment pattern of males and females into the TVET programs, the respondents were not at variance in their opinion on the factor responsible for poor female enrolment in TVET program, and Emmanuel (2015) who suggested that the respondents unanimously agreed on the factors hindering massive female enrolment in TVET program.

\section{Hypothesis 2}

There is no significant difference in the mean responses of parents and teachers on the strategies for improving female enrolment into electrical/electronics engineering trade in technical colleges of Adamawa State.

Table 4: $\quad$ z-test analysis of mean responses of teachers and parents on the strategies for improving female enrolment into electrical/electronics engineering trade in technical colleges of Adamawa State

\begin{tabular}{lcccccccc}
\hline & $\bar{x}$ & $\sigma$ & $\mathrm{n}$ & $\mathrm{df}$ & $\alpha$ & $\mathrm{z}$ & $p$ & Remark \\
\hline Teachers & 4.03 & 0.41 & 38 & & & & & \\
& & & & 176 & 0.05 & 0.15 & 0.88 & Not Significant \\
Parents & 4.02 & 0.15 & 140 & & & & & \\
\hline KEY: & $\bar{x}=$ Mean, $\sigma=$ Standard Deviation, $n=$ Number of Respondents, $d f=$ Degree of Freedom, $\alpha=$ level of \\
& $\begin{array}{l}\text { significance, } z=\text { Observed } z \text {-value, } p=\text { Significance (2-tailed }) \\
\text { Source: Authors }\end{array}$
\end{tabular}


The result on Table 4 reveals a z-value of 0.15 with a $p$-value of 0.88 . Since the $p$-value is greater than the alpha level of the test ( $p>.05)$, the null hypothesis tested is accepted. This means that there is no significant difference in the mean responses of parents and teachers on the strategies for improving the enrolment of female students into electrical/electronics engineering trade in technical colleges of Adamawa State.

\section{Conclusion and Suggestion}

One of the priorities of the United Nations Educational, Scientific and Cultural Organization (UNESCO) as captured in the SDGs 2016-2030 is to mainstream gender equality and promote equity through TVET policies and programmes. This is achievable only through policies on TVET that will make sure that all youth and adults, including vulnerable and disadvantaged groups, have equal access to learning opportunities and skills development. Therefore, UNESCO integrates gender equality in and through national TVET systems in different ways including gender-sensitive evaluations of TVET programmes. The UNESCO also supports innovative means that seeks to widen access and participation in TVET for vulnerable and disadvantaged groups.

This study thus revealed that the female gender is one of the disadvantaged groups with respect to enrolment in electrical/Electronics engineering trade. It was observed that there's a yearly decline in enrolment into the TVET programme in technical colleges of Adamawa state. This development has the potential to endanger the TVET programme and national development. Therefore, mechanisms should be put in place to adopt the strategies as captured in this study to improve female enrolment into electrical/Electronics engineering trade as investing in the education of girls brings high returns in terms of breaking cycles of poverty and social vices that the girls might be lured into, and thus aiding economic growth. Based on the findings of this study, the following invaluable suggestions were made:

The Adamawa state government in collaboration with government para-statals and Nongovernmental Organizations (NGOs) should establish a sustainable financing scheme for the female trainees of electrical/Electronics engineering trade in order to boost their interests in the programme. Provisions and favourable policies should be made to ensure a conducive environment for female trainees in electrical/Electronics engineering trade who wants to practice upon graduation. Electrical/Electronics engineering trade teachers in partnership with the state government and NGOs should organize awareness campaigns on the impact and benefits of female enrolment into the programme. This awareness campaigns will also be an avenue to abreast them with incentives that will be available to female enrolees in the programme. More female trainers should be recruited into electrical/Electronics engineering trade in order to encourage more female enrolments as the female trainers will become role models to other girls with interests. This will also help change the negative public view with regards female enrolment into the programme. 


\section{Acknowledgements}

The authors wish to acknowledge the contributions of Prof. L. C. Ezugu for having time to go through the manuscript and giving necessary guidance to the study. Special thanks also to Prof. E. V. Mbaga: the Head, Department of Electrical Technology Education, Modibbo Adama University, Yola, Nigeria for recommending all the authors for sponsorship to carry out this study. Finally, the support, approval and the finances to carry out this study was granted by the Vice Chancellor of Modibbo Adama University of Technology Yola, Prof. Abdullahi Liman Tukur. The authors are most grateful to you sir.

\section{Conflict of Interest}

The authors declares no conflict of interest

\section{Funding}

The cost and all associated financial burden for conducting the study and for publishing this article are bone by the management of the Modibbo Adama Univerity of Technology Yola, Nigeria.

\section{References}

Abdulahi, E. N. (2016). Technical vocational education and training (TVET) in Nigeria: Issues and suggestions for productivity and sustainable national development. International Journal of Research in Education, 10(1), 30-49.

Abel,G. J.,Barakat, K.S. \&Lutz,W.(2016). Meeting the sustainable development Goals leads to lower world population growth. Proceeding of National Academic andScience, 113:14294-99.

Akinduro, I. R. (2006). Electrical installation and maintenance work skills needed by technical college graduates to enhance their employment in Niger state. [Unpublished M. Ed Thesis], Department of Vocational Teacher Education, University of Nigeria, Nsukka

Allen C, Metternicht G, Wiedmann, T.(2016). National path-ways to the Sustainable Development Goals (SDGs):A comparative review of scenario modelling tools. Environmental SciencePolicy,66:199-207

Amoo, E. D. (2011). Gender academic performance in Nigerian universities: Economic implications. International Journal and Research Education, 8(1), 159-172.

Angelopulo, G. (2013). The drivers of student enrolment and retention: A stakeholder perception analysis in higher education. PerspectivesinEducation, Volume31(1), 49-65

Apagu, V. V., Zambwa, J., Quahha, D. W., and Tumba, I. (2003). A comparative analysis of gender stereotyped enrolment issues in vocational teacher education in a Nigerian university: Focus on industrial technical and agricultural programmes. Educational Forum, 6, 1-9.

Ayomike, C. S. (2014). Factors affecting female participation in technical education programme: A study of Delta State University, Abraka. Journal of Education and Human Development, 3(3), 227-240.

Buse,K, \& Hawkes, S. (2015).Health in the sustainable development goals: Ready for a 
paradigm shift? Globalization and Health 11(13), 10-16

Emmanuel, E. I. (2015). Strategies for improving students' enrolment into technical college programmes in Ebonyi State. Journal of Educational Policy and Entrepreneurial Research, 2(5), 101-107.

Ezeliora, B. and Ezeokana, J.O.(2010).Inhibiting influences of some traditional practices in the home on girl-child's scientific development. International Journal of FAWE Nigeria,2(1) $31-42$.

Gimba, S. J. (2008). Funding of community secondary schools in Bauchi state. Bauchi: Bauchi State Printing Press.

Josiah, O. and Etuk-Iven, O. A. (2014).Effect of gender age and mathematic anxiety on college students' achievement in algebra. American Journal of Educational Research, 2(7), 474 476.

Khaguya, L. (2014). Factors influencing female students' enrolment in technical courses: a case of Matilitechnical training institute, Kenya. (Unpublished Masters' Thesis), Department of Project Planning and Management of the University of Nairobi.

Krejice, R. and Morgan, D. (1970).Determining sample size of research activities. Educational Psychology Measurement, 30: $601-610$.

Nawe, J. (2002). Female participation in African universities: Effective strategies for enhancing their participation with reference to the university of Dar Es Salaam, Tanzania. Retrieved from http://repository.udsm.ac.tz:8080/xmlui/bitstream/handle/20.500.11810/432.

Okwelle, P. C. \& Agwi-Vincent, I. A. (2018).Strategies for improving female students' enrolment in technical and vocational education programmes through public relations activities in Nigeria. International Journal of Advanced Academic Research, Arts, Humanities \& Education, 4(1), 1-14

United Nations Development Programme (2019). Goal 4: Quality education. https://www.undp.org/content/undp/en/home/sustainable-development-goals/goal-4quality-education.html (Retrieved on 5th August 2019).

West, M. S. (2007). Unprecedented urgency: Gender discrimination in faculty hiring at the University of California. National Women Studies Association Journal, 19(3), 199-211.

World Health Organization (2009). Gender: Definitions. Retrieved from http://www.euro.who.int/en/health-topics/health-determinants/gender/gender-definitions 